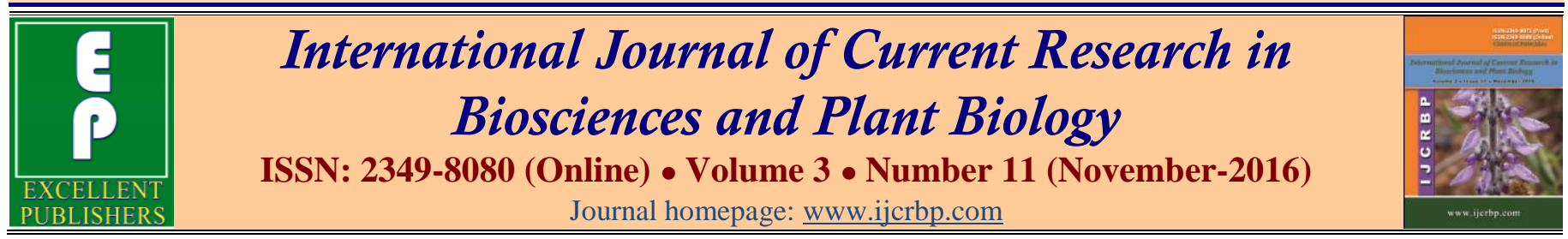

\title{
Anti-diabetic Effects of Extract of Momordica charantia (Karela) Fruits and Camel Milk Compared to Dibenol on Induced Diabetic Rats
}

\author{
Kandil Abdel-Hai Ali Attia*\$, Halima Yahya Sharahili, ShaimaAbd Al-ellah Al Harbi, Laila \\ Mohammad Mutaen, Maraym Ali Somaly and Eman Abdu Qahar
}

Department of Medical Laboratory Technology, College of Applied Medical Sciences, Jazan University, Saudi Arabia \$Current address: Department of Medical Laboratory Technology, College of Applied Medical Sciences, Jazan University, Saudi Arabia. Postal code: 82621/7431-P.O. Box: 2349

\$Permanent address: Evaluation of Natural Resources Department, Environmental Studies and Research Institute, University of El-Sadat City, El-Sadat City, Sixth Zone, Egypt

*Corresponding author.

\section{A b st ract}

This study aimed to evaluate the anti-diabetic effects of aqueous extract of karela fruits and camel milk compared to dibenol on the streptozotocin (STZ) induced diabetic rats by assaying liver and kidney functions. Forty-two male albino rats were divided into 7 equal groups. Group I were given normal feed and water, groups II and III received orally $(75 \mathrm{ml} / \mathrm{rat} /$ day $)$ camel milk and extract of karela $(800 \mathrm{mg} / \mathrm{kg})$ respectively. Intraperitoneal injection of STZ $(60 \mathrm{mg} / \mathrm{kg})$ was used for inducing diabetes mellitus in groups IV, V, VI and VII. Groups V, VI and VII treated orally with dibenol $(5 \mathrm{mg} / \mathrm{kg})$, camel milk and extract of karela respectively for 30 days. Blood glucose levels for each rat were determined before STZ dosing and after 3, 10, 30 days of administration. Blood samples were collected at the end of the experiment for estimation blood glucose concentration as well as kidney and liver functions parameters. The glucose level was decreased in rats treated with aqueous extract of karela or camel milk. Moreover, the ALT, AST, ALP enzymes, urea, creatinine and uric acid were decreased. It could be concluded that either karela or camel milk have antihyperglycemic effects and may be used to manage diabetes mellitus.
\end{abstract}

\section{Introduction}

Diabetes mellitus (DM) is considered as one of the five leading causes of death in the world (Joseph and Jini, 2011). DM is the $3^{\text {rd }}$ cause of death in Saudi Arabia (World Health Ranking, 2010). The global estimated that the prevalence of diabetes from 171 million in 2000 to 366 million in 2030 (Shaw et al., 2010). The number of people who suffer from DM increased from 890,000 in 2000 to a staggering projection of 2,523,000 in 2030 in Saudi Arabia
(Al-Baghli et al., 2010). In 2011, Saudi Arabia reported a prevalence of DM at $30 \%$ of the total population, with a rate of $27.6 \%$ in women and $34.1 \%$ in men (El-Bab et al., 2012).

DM is a group of diseases marked by high levels of blood glucose resulting from defects in insulin production from the pancreatic $\beta$-cells (Jarald et al., 2008), insulin action, or both. Diabetes is associated with the generation of reactive oxygen species which cause oxidative damage particularly 
to heart, kidney, eyes, nerves and liver (Orsolic and Basic, 2008; Obrosova et al., 2003). The disease causes morbidity and long-term complications, including cardiomyopathy, angiopathy, neuropathy, retinopathy, nephropathy, diabetic food and digestive insufficiencies (Karunanayake and Tennekoon, 1993; Yeh et al., 2003). There are different groups of oral hypoglycemic drugs and insulin for clinical use, having adverse side effects, including hematological, cutaneous and gastrointestinal reactions, hypoglycemic coma and disturbances of liver and kidney functions (Holman and Turner, 1991; Williams and Pickup, 1991; Kameswara Rao et al., 1997). Dibenol (glybincalmide) is one of an orally effective hypoglycaemic drug that reduces blood sugar concentration. It stimulates the mobilization of endogenous insulin. Management of diabetes without any side effects is still a challenge to the medical system. This leads to increasing the demand for complementary and alternative medicine with antidiabetic activity and fewer side effects. Several studies showed that Momordica charantia has anti-diabetic, anti-viral, anti-tumour, antioxidant, anti-inflammatory and hypo-chlolestrolemic, hypoglyceridemic and immune-stimulant properties (Biswas et al., 1991; Ahmed et al., 1999; Naseem et al., 1998). Camel's milk (CM) is an excellent source of wellbalanced nutrients and exhibits a range of biological activities. CM used therapeutically against dropsy, jaundice, problems of the spleen, tuberculosis, asthma, anemia, piles and diabetes. It also has antibacterial and antiviral activities (Agrawal et al., 2005; Redwan and Tabll, 2007).Therefore, the aim of the present study was to evaluate the anti-diabetic effects of extract of karela fruits and camel milk compared to dibenol (synthetic medicine) on blood glucose level, liver and kidney functions on the streptozotocin induced diabetic rats.

\section{Materials and methods}

This investigation was carried out in the labs of Medical Laboratory Technology Department, College of Applied Medical Sciences, and Medical Research Center, Jazan University.

\section{Preparation of the aqueous extract of $M$. charantia fruits}

The fruits of $M$. charantia were collected from local market in Jazan city. To obtain karela fruits aqueous extract, this unripe fresh karela fruits were carefully and thoroughly washed in tap water. The fruits were sliced into two halves and the seeds were removed manually, then the fleshy parts were cut into small pieces. Then 1 $\mathrm{kg}$ seedless flesh was put into an electric juicer to make juice and it is then filtered through a piece of clean silk cloth. The filtered juice was evaporated to slurry in vacuum rotatory evaporator and temperature was maintained around $45^{\circ} \mathrm{C}$, and the concentrated slurry mass was completely lyophilized by continuous freeze drying operation for $72 \mathrm{hrs}$ and kept at $-20^{\circ} \mathrm{C}$ in refrigerator in air tight container until use.

\section{Chemicals and kits}

Streptozotocin, glibenclamide and diagnostic kits for liver and kidney functions such as ALT, AST, ALP, urea, uric acid, and creatinine were purchased from the Sigma-Aldrich Co.

\section{Camel milk}

The milk was collected from female lactating healthy domestic camels (Camelus dromedaries). The samples were collected from desert living animals in Jazan region, Kingdom of Saudi Arabia, then after were transported in icebox in two hours to lab.

\section{Maintenance of animals and approval of protocol}

Forty-two healthy male albino rats of Wistar strain, weighing 220-280 g, were used for the present investigation. They were housed in clean cages and maintained in an air-conditioned experimental room at 12-hr light: dark cycles. The animals were acclimatized to laboratory condition for one week prior to experiment. Standard pellets were used as a basal diet during the experimental period. The control and experimental animals were provided with purified drinking water ad libitum. The animals were maintained in accordance with according to the European Communities Council Directive of 1986 (EC 86/609) and approved by the Ethical Committee for Animal Experimentation at Medical Research Center, Jazan University. Before starting the experiment, the animals were carefully marked on different parts of their body, which was later used as identification mark for a particular animal, so that the response of a particular mouse prior to and after the administration could be noted separately.

\section{Induction of diabetes in experimental animals}

Diabetes mellitus was induced in overnight fasted rats by a single intraperitoneal injection of streptozotocin at the rate of $60 \mathrm{mg} / \mathrm{kg}$ body weight dissolved in $10 \mathrm{mM}$ sodium citrate buffer ( $\mathrm{pH} 4.5)$, while the control group was given only normal feed and water (Saeed et al., 
2008). The animals were allowed free access to $5 \%$ glucose solution to overcome the drug induced hypoglycaemia. Blood glucose level of these rats was estimated $72 \mathrm{hr}$ after streptozotocin administration, and diabetes was confirmed by blood samples collected from the tip of the tail using a blood glucometer. Animals with blood glucose level equal to or more than $200 \mathrm{mg} / \mathrm{dL}$ were declared diabetic and were used in entire experimental groups (Lenzen, 2008).

\section{Experimental designs}

Seven groups of rats, six rats in each, received the following treatment schedule:

Group I: Normal control rats were given only normal feed and water.

Group II: Rats received camel milk $(75 \mathrm{~mL} / \mathrm{rat} /$ day $)$ for 30 days.

Group III: Received aqueous extract of $M$. charantia fruit $(800 \mathrm{mg} / \mathrm{kg}$ dissolved in $10 \mathrm{ml}$ distilled water) by stomach tube.

Group IV: Rats subjected to intraperitoneal injection (i.p.) of STZ $(60 \mathrm{mg} / \mathrm{kg})$ used for inducing diabetes mellitus.

Group V: Rats of STZ induced DM were treated with dibenol (glibenclamide $5 \mathrm{mg} / \mathrm{kg}$, suspended in $10 \mathrm{ml}$ distilled water) up to day 30 .

Group VI: Rats of STZ induced DM were orally received camel milk $75 \mathrm{ml} /$ rat/day for 30 days.

Group VII: Rats of STZ induced DM were orally received aqueous extract of $M$. charantia fruit $(800 \mathrm{mg} / \mathrm{kg}$ dissolved in $10 \mathrm{ml}$ distilled water) for 30 days.

\section{Collection of blood samples and estimation of serum} biochemical investigations

After the last dose, animals were fasted for 12 hours and the rats were anesthetized by diethyl ether. Blood was drawn via heart puncture into tubes. Serum was separated from the clot by centrifuging at $3000 \mathrm{rpm}$ for $15 \mathrm{~min}$ at room temperature. Serum was collected carefully and kept at $-20 \circ \mathrm{C}$ until analysis of fasting blood glucose concentration was determined by commercially available glucose kit based on Trinder (1969). Spectrophotometric diagnostic kits were used for estimation kidney and liver function tests including determination of ALT, AST and ALP activities (Moss, 1982; Young, 1990), urea (Fawcett and Scott, 1960), uric acid (Fossati et al., 1980), and creatinine levels (Stein, 1986) in serum.

\section{Body weight}

The body weight of rat of each group was measured just before and 10; 30 days after induction of diabetes and administration of karela, camel milk and dibenol.

\section{Statistical analysis}

Data from the experiments were presented as mean \pm standard deviation. Statistical analysis was done by using the SPSS for Windows. The level of significance was set at $p<0.01$.

\section{Results and discussion}

Diabetes mellitus is a serious disease with multiple complications that is rising dramatically worldwide. STZ is the drug that selectively destroys $\beta$ cells, insulin producing pancreatic endocrine cells, and thus induces experimental diabetes mellitus (Brenna et al., 2003).

The present study showed that daily treatment for 30 days with raw camel $(75 \mathrm{ml} / \mathrm{rat})$ has anti-hyperglycemic effect for the STZ-diabetic rats where mean blood glucose level reduced significantly from $383 \pm 70.4$ to $264 \pm 30.3$ (Table 1). These results are in agreement with Khan et al. (2013) who reported that the blood glucose levels of diabetic rats that were fed fresh camel milk reduced significantly from $560 \mathrm{mg} / \mathrm{dL}$ to $235 \mathrm{mg} / \mathrm{dL}$ after 30 days. Also, Badr (2013) found that STZ-induced diabetic mice treated with camel milk whey protein displayed a significant reduction in blood glucose levels from $411 \pm 37 \mathrm{mg} / \mathrm{dL}$ to $261 \pm 25.5 \mathrm{mg} / \mathrm{dL}$ after 2 weeks. Similar results were reported by Agrawal et al. (2005) in rats; Agrawal et al. (2011) in human; El-Said et al. (2010) in rabbits and Sboui et al. (2010) in dogs. This reduction may be related to the presence of 52 micro unit $/ \mathrm{ml}$ of insulin-like protein in camel milk which mimic insulin interaction with its receptor. Moreover, the higher content of zinc in camel milk (Mehaia et al., 1995) has a key role in insulin secretory activity in pancreatic beta cells. Beg et al. (1986) found that the amino acid sequence of some camel milk protein is rich in cysteine/half-cystine, which has a superficial similarity with the insulin family peptides. In addition, camel milk possesses a different casein content, a high amount of both polyunsaturated fatty acids (C18:1$\mathrm{C} 18: 3$ ) and vitamin $\mathrm{B}_{3}$ and large lipid micelles (Farah, 1993 and Al-Humaid et al., 2010). Furthermore, the small size and weight of camel milk immunoglobulin may offer enormous potential through interaction with the host cell protein and cause an induction of regulatory 
cells and finally result in a downward regulation of the immune system and $\beta$-cell salvage (Agrawal et al., 2007a, b).

The current study indicated that aqueous extract of $M$. charantia for a period of 30 days $(800 \mathrm{mg} / \mathrm{kg})$ produced a significant reduction in the blood glucose levels of the STZ-diabetic rats from $337.5 \pm 32.8$ to $272.3 \pm 15.7$ (Table 1). These results are consistent with data reported by Hossain et al. (2014) who found that administration of aqueous extract of $M$. charantia fruits by $750 \mathrm{mg} / \mathrm{kg}$ in rats was able to reduce blood glucose level significantly compared with the diabetic control group. Also Ragasa et al. (2011) and Sarandan et al. (2010) confirmed that various extracts and compounds of $M$. charantia have antidiabetic properties. In other studies, on rabbits $M$. charantia extract had a hypoglycemic effect (Akhtar et al., 2011). They attributed this effect to the saponin and glycosidic components present in the plant. A number of reported clinical studies have shown that $M$. charantia extract from the fruits, seeds and leaves contains several bioactive compounds that have hypoglycemic activity in both diabetic animals and human (Wehash et al., 2012; Fuangchan et al., 2011) .These bioactive components may work as ligands for peroxisome proliferator activated receptors, ligand-activated transcription factors important in modulating both lipid and glucose metabolism (Chuang et al., 2006; Chao and Huang, 2003).

The hypoglycemic effect of $M$. charantia may be attributed to its content of a peptide resembling insulin (charantin) (Parkash et al., 2002). The decrease in the blood glucose level in the present treated animals could be related either to the partial regeneration or the preservation of the pancreatic $\beta$ cell mass by $M$. charantia in rats (Hossain et al., 2014; Ahmed et al., 1999). Finally, another potential hypoglycemic mechanism of action of $M$. charantia is by decreasing $\mathrm{Na}^{+}$and $\mathrm{K}^{+}$-dependent glucose absorption at the brush border membrane (Meir and Yaniv, 1985; Singh et al., 2004) and inhibiting intestinal monosaccharide and amino acid uptake (Mahomoodally et al., 2004). Moreover, $M$. charantia has been shown to modulate activities of intestinal and renal disaccharidases in STZinduced diabetic rats (Shetty et al., 2005). The results declared that the ameliorative effect by camel milk was higher than either karela or dibenol on blood glucose levels as shown in Table 1.

Table 1. Influence of karela, camel milk and dibenol administration on blood glucose levels $\mathrm{mg} / \mathrm{dL}$ (mean \pm STD) of diabetic rats comparing to control untreated groups.

\begin{tabular}{llll}
\hline Group no. & Baseline & After 10 days & After 30 days \\
\hline Group I & $116.2^{\mathrm{a}} \pm 8.2$ & $123.8^{\mathrm{a}} \pm 8.9$ & $120.3^{\mathrm{a}} \pm 11.5$ \\
Group II & $104.3^{\mathrm{a}} \pm 6.9$ & $115^{\mathrm{a}} \pm 13.02$ & $118.3^{\mathrm{a}} \pm 3.5$ \\
Group III & $127.8^{\mathrm{a}} \pm 15.2$ & $105.2^{\mathrm{a}} \pm 9.2$ & $105.8^{\mathrm{a}} \pm 7.6$ \\
Group IV & $360.4^{\mathrm{b}} \pm 26.6$ & $377.6^{\mathrm{b}} \pm 16.1$ & $376.6^{\mathrm{b}} \pm 8.9$ \\
Group V & $359.5^{\mathrm{b}} \pm 14.7$ & $341^{\mathrm{c}} \pm 26.2$ & $290.3^{\mathrm{c}} \pm 8.5$ \\
Group VI & $383^{\mathrm{c}} \pm 70.4$ & $300.5^{\mathrm{d}} \pm 29.6$ & $264^{\mathrm{d}} \pm 30.3$ \\
Group VII & $337.5^{\mathrm{b}} \pm 32.8$ & $306.7^{\mathrm{d}} \pm 17.7$ & $282.8^{\mathrm{c}} \pm 42.3$ \\
\hline
\end{tabular}

Values are means of 6 rats \pm STD. Means with different superscripts in the same column are significantly different $(p<0.01)$.

Table 2. Effects of karela, camel milk and dibenol on body weight $(\mathrm{gm}$.) (mean \pm STD) in diabetic rats comparing to control untreated groups.

\begin{tabular}{llll}
\hline Group no. & Baseline & After 10 days & After 30 days \\
\hline Group I & $269.5^{\mathrm{b}} \pm 19$ & $283.2^{\mathrm{a}} \pm 27.4$ & $284.7^{\mathrm{a}} \pm 26$ \\
Group II & $260.5^{\mathrm{b}} \pm 18.2$ & $275^{\mathrm{a}} \pm 21.2$ & $280.2^{\mathrm{a}} \pm 9.3$ \\
Group III & $241^{\mathrm{c}} \pm 11.2$ & $258.2^{\mathrm{b}} \pm 4.9$ & $244.3^{\mathrm{c}} \pm 18.7$ \\
Group IV & $259.5^{\mathrm{b}} \pm 18.7$ & $223.2^{\mathrm{c}} \pm 19.9$ & $195.7^{\mathrm{d}} \pm 14.6$ \\
Group V & $271.8^{\mathrm{a}} \pm 15.2$ & $210.2^{\mathrm{b}} \pm 7.8$ & $196.8^{\mathrm{d}} \pm 7.2$ \\
Group VI & $256^{\mathrm{b}} \pm 5.1$ & $185^{\mathrm{d}} \pm 9.6$ & $177^{\mathrm{c}} \pm 10.7$ \\
Group VII & $229^{\mathrm{c}} \pm 5.1$ & $202.3^{\mathrm{b}} \pm 10.8$ & $197.2^{\mathrm{b}} \pm 7.7$ \\
\hline
\end{tabular}

Values are means of 6 rats \pm STD. Means with different superscripts in the same column are significantly different $(p<0.01)$.

The present data revealed that the body weight after 30 days of treatment in untreated control groups (Groups I, II and III) were significantly increased than at the beginning of the experiment, on the contrary a significant decrease body weight was observed in diabetic treated group (Group IV) $(p<0.01)$ (Table 2). On the other hand, the administration of camel milk or aqueous extracts of $M$. charantia to the diabetic animals (Groups VI and VII respectively) showed slightly improvement in the body weight. These changes in body weights in all groups of 
animals were given in Table 1 . These results are in agreement with Ahn et al. (2006) who showed that the body weight was significantly decreased in STZ-diabetic rats. The ability of $M$. charantia or camel milk to protect body weight loss seems to be due to their ability to reduce hepato-renal dysfunction. They might enhance glucose utilization and improve diabetes associated disorders because it significantly decreased the blood glucose level as in Table 1.

Elevation in the liver enzymes such as alanine aminotransferase (ALT) and aspartate aminotransferase (AST) in diabetic patients reflect the concentration of intracellular hepatic enzymes that have leaked into the circulation and serve as a marker of hepatocyte injury (Harris, 2005). The current study indicated that ALT, AST, ALP, urea, creatinine and uric acid were significantly elevated in STZ -DM rats as compared to control groups (Groups I, II and III) as shown in Tables 3 and 4. While administration either camel milk or aqueous extracts of $M$. charantia (Groups VI and VII respectively) to the induced diabetic rats showed that ameliorative effects of liver and kidney functions parameters as compared to positive diabetic control group (Group IV) (Table 3). These results are in agreement with Hamad et al. (2011), Khan et al. (2013), and, Korish and Arafah (2013). The beneficial health effects of camel milk to the liver and kidney function could be attributed to its antioxidant activity (Al-Humaid et al., 2010). It has been reported that camel milk contains high levels of vitamins (A, B2, C and E) and is rich in magnesium (Knoess, 1979). These vitamins are antioxidants that have been found useful in preventing tissue injury caused by toxic agents like STZ (Yakaryilmaz et al., 2007). Additionally, camel milk is rich in Zinc (Knoess, 1979), a trace element essential for living organisms. More than 300 enzymes require $\mathrm{Zn}$ for their activity and it has a relationship with many enzymes in the body and can prevent cell damage through activation of antioxidant system (Powell, 2000; Ozturk et al., 2003; Ozdemir and Inane, 2005).

The bioactive components of aqueous extracts of $M$. charantia may be responsible for many of the proposed health benefits such as charantin, glycosides such as mormordin, antioxidants such as vitamin $\mathrm{C}$, carotenoids, flavanoids, and polyphenols and polypeptide $\mathrm{p}$ or plant insulin (Khanna et al., 1981; Lotlikar and Rajarama Rao, 1966; Jantan et al., 2005; Anila and Vijayalakshmi, 2000). The present study showed that the administration of karela in Group VII significantly reduced AST and ALP activity followed by dibenol (Group V) and camel milk (Group VI) respectively as shown in Table 3. While dibenol was higher effective than either karela or camel milk on reduction of activity of ALT enzyme. Moreover, administration of karela was more effective on reduction of serum creatinine and urea than either camel milk or dibenol. On the contrary, the dibenol has a significant effect on reduction of serum uric acid followed by camel milk and karela respectively (Table 4).

Table 3. Influence of karela, camel milk and dibenol administration on liver functions (IU/L) (mean \pm STD).

\begin{tabular}{llll}
\hline Group no. & AST & ALT & ALP \\
\hline Group I & $176.5^{\mathrm{a}} \pm 52.9$ & $89.3^{\mathrm{a}} \pm 12.7$ & $361.1^{\mathrm{a}} \pm 56.7$ \\
Group II & $165.6^{\mathrm{a}} \pm 44.7$ & $71.7^{\mathrm{a}} \pm 14.9$ & $351.4^{\mathrm{a}} \pm 42.8^{\mathrm{m}}$ \\
Group III & $158.3^{\mathrm{a}} \pm 22.2$ & $70.7^{\mathrm{a}} \pm 7.8$ & $274.3^{\mathrm{b}} \pm 67.1^{\mathrm{b}}$ \\
Group IV & $215.7^{\mathrm{b}} \pm 59.9$ & $143.8^{\mathrm{b}} \pm 43.4$ & $635.5^{\mathrm{c}} \pm 69.7$ \\
Group V & $152.3^{\mathrm{a}} \pm 49.9$ & $111.8^{\mathrm{c}} \pm 17.6$ & $255.7^{\mathrm{d}} \pm 55.1$ \\
Group VI & $184.5^{\mathrm{a}} \pm 5.9$ & $134.9^{\mathrm{b}} \pm 18.7$ & $372.9^{\mathrm{a}} \pm 39.9$ \\
Group VII & $135.7^{\mathrm{c}} \pm 44.7$ & $131^{\mathrm{b}} \pm 41.9$ & $282.8^{\mathrm{b}} \pm 42.3$ \\
\hline
\end{tabular}

Values are means of 6 rats \pm STD. Means with different superscripts in the same column are significantly different $(p<0.01)$.

Table 4. Influence of karela, camel milk and dibenol administration on kidney functions (mean \pm STD).

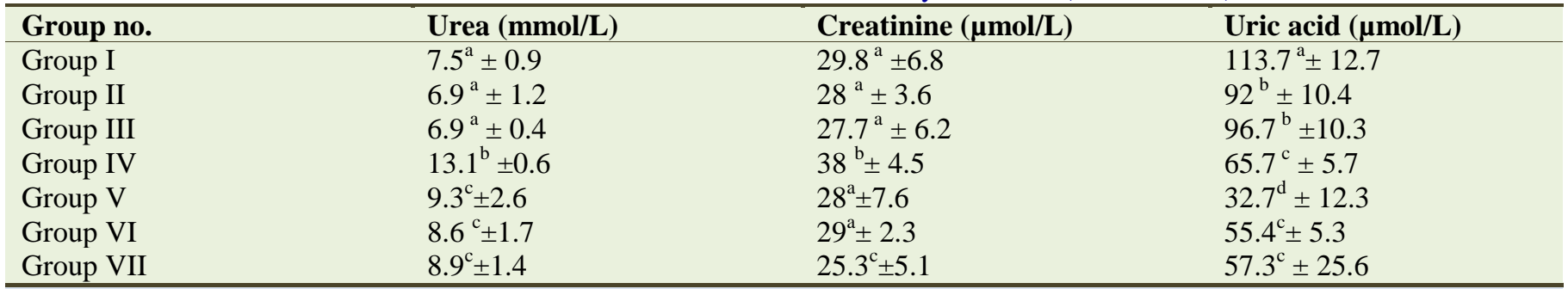

Values are means of 6 rats \pm STD. Means with different superscripts in the same column are significantly different $(p<0.01)$. 


\section{Conclusion}

It could be concluded that, camel milk or aqueous extracts of $M$. charantia has a powerful effect in reducing blood glucose levels and they limit diabetic complications such as elevated markers enzymes and parameters of liver and kidney diseases in rats. Camel milk and $M$. charantia has a significant role in treatment of diabetes may due to its content of insulin/insulin-like proteins. So camel milk and karela fruits are important for human especially diabetic patients. Further studies are needed to isolate the actual bioactive peptides, in camel milk and karela fruits, which responsible for reducing blood glucose, markers enzymes and parameters of liver and kidney in diabetic patients.

\section{Conflict of interest statement}

Authors declare that they have no conflict of interest.

\section{Acknowledgement}

We are keenly grateful to Scientific Research Deanship, Jazan University for supporting this work by grant number FS3-035. Also we are thankful to Medical Research Center for providing us with the animal models. Finally, we are very grateful to the supervisor of animal house of Medical Research Center Dr. Emad ElSayed Shahin, for assisting during practical part in animal house.

\section{References}

Agrawal, R.P., Jain, S., Shah, Chopra, A., Agarwal, V., 2011. Effect of camel milk on glycemic control and insulin requirement in patients with type 1 diabetes: 2-years randomized controlled trial. Eur. J. Clin. Nutr. 65, 10481052.

Agrawal, R.P., Budania, S., Sharma, P., Gupta, R., Kochar, D.K., Panwar, R.B.andSahani, M.S., 2007a. Zero prevalence of diabetes in camel milk consuming Raica community of north-west Rajasthan, India. Diabet. Res. Clin. Pract. 76, 290-296.

Agrawal, R.P., Saran, S., Sharma, P., Gupta, R.P., Kochar, D.K., Sahani, M.S., 2007b. Effect of camel milk on residual beta-cell function in recent onset type 1 diabetes, Diabet. Res. Clin. Pract. 77, 494-495.

Agrawal, R.P., Beniwal, R., Kochar, D.K., Tuteja, F.C., Ghorui, S.K., Sahani, M.S., Sharma, S., 2005. Camel milk as an adjunct to insulin therapy improves long-term glycemic control and reduction in doses of insulin in patients with type-1 diabetes: A 1 year randomized controlled trial. Diabet. Res. Clin. Pract. 68, 176-177.

Ahmed, N., Hassan, M.R., Halder, H., Bennoor, K.S., 1999.
Effect of Momordica charantia (Karolla) extracts on fasting and postprandial serum glucose levels in NIDDM patients. Bangl. Med. Res. Coun. Bull. 25, 11-13.

Ahn, T., Yun, C. H., Oh, D.B., 2006. Tissue specific effect of ascorbic acid supplementation on the expression of cytochrome P450 2EI and oxidative stress in streptozotocin-induced diabetic rats. Toxi. Let. 166, 2736.

Akhtar, N., Khan, B.A., Majid, A., Khan, H. M., Mahmood, T., 2011. Pharmaceutical and biopharmaceutical evaluation of extracts from different plant parts of indigenous origin for their hypoglycemic responses in rabbits. Acta Pol. Pharm. 68(6), 919-925.

Al-Baghli, N.A., Al-Ghamdi, A.J., Al-Turki, K.A., Al Elq, A.H., El-Zubaier, A.G., Bahnassy, A., 2010. Prevalence of diabetes mellitus and impaired fasting glucose levels in the Eastern Province of Saudi Arabia: Results of a screening campaign. Singapore Med. J. 51(12), 923-30.

Al-Humaid, A.I., Mousa, H.M., El-Mergawi, R.A., AbdelSalam, A.M., 2010. Chemical composition and antioxidant activity of dates and dates-camel-milk mixtures as a protective meal against lipid peroxidation in rats. Am. J. Food Technol. 5, 22-30.

Anila, L., Vijayalakshmi, N. R., 2000. Beneficial effects of flavonoids from Sesamum indicum, Emblica officinalis and Momordica charantia. Phytother. Res. 14, 592-595.

Badr, G., 2013. Camel whey protein enhances diabetic wound healing in a streptozotocin-induced diabetic mouse model: the critical role of $b$-defensin-1, -2 and -3 . Lipids Health Dis. 12, 46.

Beg, O.U., von-Bahr-Lindststrom, H., Zaidi, Z. H., Jornvall, H., 1986. Characterisation of camel milk protein rich proline identifies new beta casein fragment. Regul. Pept. $15,55-62$.

Biswas, A.R., Ramaswamy, S., Bapna, J.S., 1991. Analgesic effect of Momordica charantia seed extract in mice and rats. J. Ethnopharmacol. 31, 115-118.

Brenna, O., Qvigstad, G., Brenna, E., Waldum, H. L., 2003. Cytotoxicity of streptozotocin on neuroendocrine cells of the pancreas and the gut. Dig. Dis. Sci. 48(5), 906-910.

Chao, C. Y., Huang, C. J., 2003. Bitter gourd (Momordica charantia) extract activates peroxisome proliferatoractivated receptors and upregulates the expression of the acyl CoA oxidase gene in H4IIEC3 hepatoma cells. J. Biomed. Sci. 10, 782-791.

Chuang, C. Y., Hsu, C., Chao, C. Y., Wein, Y. S., Kuo, Y. H., Huang, C. J., 2006. Fractionation and identification of 9c, 11t, 13t-conjugated linolenic acid as an activator of PPAR alpha in bitter gourd (Momordica charantia L.). J. Biomed. Sci. 13, 763-772.

El-Bab, M., Shawky, N., Al-Sisi, A., Akhtar, M., 2012. Retinopathy and risk factors in diabetic patients from AlMadinah Al-Munawarah in the Kingdom of Saudi Arabia. Clin. Ophthalmol. 6(1), 269-276.

El-Said, E.E., El-Sayed, G.R., Tantawy, E., 2010. Effect of camel milk on oxidative stresses in experimentally induced diabetic rabbits. Vet. Res. Forum. 1, 30-43. 
Farah, Z., 1993. Composition and characteristics of camel milk. J. Dairy Res. 60, 603-626.

Fawcett, J. K., Scott, J. E., 1960. A rapid and precise method for the determination of urea. J. Clinic. Pathol. 13, 156159.

Fossati, P., Prencipe, L., Berti, G., 1980. Use of 3,5-dichloro2-hydroxybenzenesulfonic acid/4-aminophenazone chromogenic system in direct enzymic assay of uric acid in serum and urine. Clin. Chem. 26(2), 227-231.

Fuangchan, A., Sonthisombat, P., Seubnukarn, T., Chanouan, R., Chotchaisuwat, P., Sirigulsatien, V., 2011. Hypoglycemic effect of bitter melon compared with metformin in newly diagnosed type 2 diabetes patients. J. Ethnopharmacol. 134(2), 422-428.

Hamad, E.M., Abdel-Rahim, E.A., Romeih, E.A., 2011. Beneficial effect of camel milk on liver and kidneys function in diabetic Sprague-Dawley rats. Int. J. Dairy Sci. 6, 190-197.

Harris, E. H., 2005. Elevated liver function tests in type 2 diabetes. Clin. Diabet. 23, 115-119.

Holman, R.R., Turner, R.C., 1991. Oral agents and insulin in the treatment of NIDDM. In: Text Book of Diabetes (Eds.: Pickup, J., Williams, G.). Blackwell, Oxford. pp.467-469.

Hossain, M. A., Mostofa, M., Abdul Awal, M., Chowdhury, E. H., Sikder, M. H., 2014. Histomorphological and morphometric studies of the pancreatic islet cells of diabetic rats treated with aqueous extracts of Momordica charantia (karela) fruits. Asian Pac. J. Trop. Dis.. 4(Suppl. 2), S698-S704.

Jantan, I., Rafi, I. A., Jalil, J., 2005. Platelet-activating factor (PAF) receptor-binding antagonist activity of Malaysian medicinal plants. Phytomed. 12, 88-92.

Jarald, E., Joshi, S.B., Jain, D.C., 2008. Diabetes and herbal medicines. Iran. J. Pharmacol. Therap. 7, 97-106.

Joseph, B., Jini, D., 2011. Insight into the hypoglycaemic effect of traditional Indian herbs used in the treatment of diabetes. Res. J. Med. Plant. 5(4), 352-376.

Kameswara Rao, B., Gir, R., Kesavulu, M.M., Apparao, Ch., 1997. Herbal medicines: In the treatment of diabetes mellitus. Manphar. Vaidya Patrika. 1(4/5), 33-35.

Karunanayake, E.H., Tennekoon, K.H., 1993. Search of novel hypoglycaemic agents from medicinal plants. In: Diabetes Mellitus and Its Complications (Ed.: Sharma, A.K.). An Update, Macmillan India Ltd., New Delhi, India.

Khan, A.A., Alzohairy, M.A., Mohieldein, A.H., 2013. Antidiabetic effects of camel milk in streptozotocininduced diabetic rats. Am. J. Biochem. Mol. Biol. 3, 151158.

Khanna, P., Jain, S. C., Panagariya, A., Dixit, V. P., 1981. Hypoglycemic activity of polypeptide-p from a plant source. J. Nat. Prod. 44, 648-655.

Knoess, K.H., 1979. Milk production of the dromedary. Proceedings of the $1^{\text {st }}$ International Symposium on Camels, December 18-20, Sudan. pp.201-214.

Korish, A.A., Arafah, M.M., 2013. Camel milk ameliorates steatohepatitis, insulin resistance and lipid peroxidation in experimental non-alcoholic fatty liver disease. BMC
Compl. Altern. Med. 13, 264.

Lenzen, S., 2008. The mechanisms of alloxan- and streptozotocin induced diabetes. Diabetol. 51(2), 216-226.

Lotlikar, M. M., Rajarama Rao, M. R., 1966. Pharmacology of a hypoglycaemic principle isolated from fruit of Momordica charantia Linn. Indust. J. Pharmacol. 28, 129. 133.

Mahomoodally, M. F., Fakim, A. G., Subratty, A. H., 2004. Momordica charantia extracts inhibit uptake of monosaccharide and amino acid across rat everted gut sacs in vitro. Biol. Pharmaceut. Bull. 27, 216-218.

Mehaia, M.A., Hablas, M.A., Abdel-Rahman, K.M., El-Mougy S.A., 1995. Milk composition of Majaheim, Wadah and Hamra camels in Saudi Arabia. Food Chem. 52, 115-122.

Meir, P., Yaniv, Z., 1985. An in vitro study on the effect of Momordica charantia on glucose uptake and glucose metabolism in rats. Planta Med. 1, 12-16.

Moss, D.W., 1982. Alkaline phosphatase isoenzymes. Clin. Chem. 28, 2007-2016.

Naseem, M.Z., Patil, S.R., Patil, S.R., Ravindra-Patil R.S., 1998. Antispermatogenic and androgenic activities of Momordica charantia (karela) in albino rats. J. Ethnopharmacol. 61, 9-16.

Obrosova, I. G., Minchenko, A. G., Vasupuram, R., White, L., Abatan, O. I., Kumagai, A. K., Frank, R. N., Stevens, M. J., 2003. Aldose reductase inhibitor fidarestat prevents retinal oxidative stress and vascular endothelial growth factor overexpression in streptozotocin-diabetic rats. Diabet. 52(3), 864-871.

Orsolic, N., Basic, I., 2008. Honey bee products and their polyphenolic compounds in treatment of diabetes. In: Phytopharmacology and Therapetutic Values IV (Eds.: Goviland, J. N., Singh, V. K.). Vol. 22, Stadium Press. pp.455-471.

Ozdemir, G., Inanc, F., 2005. Zinc may protect remote ocular injury caused by intestinal ischemia reperfusion in rats. Tohoku J. Exp. Med. 206, 247-251.

Ozturk, A., Baltaci, A.K., Mogulkoc, R., Oztekin, E., Sivrikaya, A., Kurtoglu, E., Kul, A., 2003. Effects of zinc deficiency and supplementation on malondialdehyde and glutathione levels in blood and tissues of rats performing swimming exercise. Biol. Trace Elem. Res. 94, 157-166.

Parkash, A., Ng, T.B., Tso, W.W., 2002. Purification and characterization of charantin, a napin-like ribosomeinactivating peptide from bitter gourd (Momordica charantia) seeds. J.Pept. Res. 59(5), 197-202.

Powell, S. R., 2000. The antioxidant properties of zinc. J. Nutr. 130, 1447-1454.

Ragasa, C.Y., Alimboyoguen, A.B., Shen, C.C., Del Fierro, R.S., Raga, D.D., 2011. Hypoglycemic effects of tea extracts and sterols from Momordica charantia. J. Natur. Remed. 11(1), 44-53.

Redwan, E. R. M., Tabll, A., 2007. Camel lactoferrin markedly inhibits Hepatitis C Virus genotype 4 infection of human peripheral blood leukocytes. J. Immun. Immunochem. 28, 267-277.

Saeed, M. K., Deng, Y., Dai, R., 2008. Attenuation of 
biochemical parameters in streptozotocin-induced diabetic rats by oral administration of extracts and fractions of Cephalotaxus sinensis. J. Clin. Biochem. Nutr. 42, 21-28.

Sarandan, H., Botau, D., Ianculov, I., Radu, F., Rada, O., Morar, D., et al., 2010. The hypoglicemic effect of Momordica charantia Linn. in normal and alloxan induced diabetic rabbits. Scient. Papers: Anim. Sci. Biotechnol. 43(1), 516-518.

Sboui, A., Khorchani, T., Djegham, M., Agrebi, A., Elhatmi, H., Belhadj, O., 2010. Antidiabetic effect of camel milk in alloxan-induced diabetic dogs: A dose-response experiment, J. Anim. Physiol. Anim. Nutr. 94, 540-546.

Shaw, J.E., Sicree, R.A., Zimmet, P.Z., 2010. Global estimates of the prevalence of diabetes for 2010 and 2030. Diabet. Res. Clin. Pract. 87(1), 4-14.

Shetty, A. K., Kumar, G. S., Sambaiah, K., Salimath, P. V., 2005. Effect of bitter gourd (Momordica charantia) on glycaemic status in streptozotocin induced diabetic rats. Plant Food. Human Nutr. 60, 109-112.

Singh, J., Adeghate, E., Cummings, E., Giannikipolous, C., Sharma, A. K., Ahmed, I., 2004. Beneficial effects and mechanism of action of Momordica charantia juice in the treatment of streptozotocin-induced diabetes mellitus in rat. Mol. Cell. Biochem. 261, 63-70.

Stein, E.A., 1986. In: Tiez, N.W. (Ed.), Clinical Chemistry. Saunder W.B., Philadelphia. pp.879-886.

Trinder, P., 1969. Determination of glucose in blood using glucoseoxidase with an alternative oxygen acceptor. Ann. Clin. Biochem. 6, 24-27.

Wehash, F.E., Abpo-Ghanema, II, Saleh, R.M., 2012. Some physiological effects of Momordica charantia and Trigonella foenum-graecum extracts in diabetic rats as compared with cidophage ${ }^{\circledR}$. World Acad. Sci. Engg. and Technol. 64, 1206-1214.

Williams, G., Pickup, J.C., 1991. New drugs in the management of diabetes mellitus. In: Text Book of Diabetes (Eds.: Pickup, J.C., Williams, G.). Vol. 11. Blackwell, Oxford. pp.977-993.

World Health Ranking, 2010. Health Profile: Saudi Arabia, Saudi Arabian Total Death by Cause 2010; http://www.worldlifeexpectancy.com/country-healthprofile/saudi-arabia

Yakaryilmaz, F., Guliter, S., Savas, B., Erdem, O., Ersoy, R., Erden, E., Akyol, G., Bozkaya, H., Ozenirler, S., 2007. Effects of vitamin E treatment on peroxisome proliferatoractivated receptor alpha expression and insulin resistance in patients with non-alcoholic steatohepatitis: Results of a pilot study. Int. Med. J. 37, 229-235.

Yeh, G.Y., Eisenberg, D.M., Kaptchuk, T.J., Phillips, R.S., 2003. Systemic review of herbs and dietary supplements for glycemic control in diabetes. Diabet. Care. 26(4), 1277-1294.

Young, D.S., 1990. Effects of Drugs on Clinical Laboratory Tests. $3^{\text {rd }}$ Edn. AACC Press, Washington, DC. pp.6-12.

\section{How to cite this article:}

Attia, K. A. A., Yahya Sharahili, H., Abd Al-ellah Al Harbi, S., Mohammad Mutaen, L., Ali Somaly, M., Abdu Qahar, E., 2016. Anti-diabetic effects of extract of Momordica charantia (Karela) fruits and camel milk compared to dibenol on induced diabetic rats. Int. J. Curr. Res. Biosci. Plant Biol. 3(11), 1-8.

doi: http://dx.doi.org/10.20546/ijcrbp.2016.311.001 